\title{
On Implementation of Intersectionality in Prosecuting and Adjudicating Mass Atrocities by the International Criminal Court
}

\author{
Gregor Maučec \\ Marie Skłodowska-Curie Postdoctoral Fellow, iCourts-Center of Excellence \\ for International Courts, University of Copenhagen Faculty of Law, \\ Karen Blixens Plads 16, 230o, Copenhagen S, Denmark \\ gregor.maucec@jur.ku.dk,gregor.mauchec@gmail.com
}

\begin{abstract}
This article examines the relevant case law of the International Criminal Court (hereafter ICC or Court) in order to assess the actual scope, confines and prospects of taking 'intersectionality' perspective in the Court's prosecution and adjudication of mass atrocities involving discriminatory targeting. While the ICC Prosecutor and judges traditionally resorted to uni-sectional analysis in considering such atrocities, some of the Court's more recent jurisprudence subsequent to the adoption of the ICC Prosecutor's Policy Papers on Sexual and Gender-Based Crimes (2014) and on Children (2016) seems to be indicative of a more intersectionality-friendly approach to prosecuting and adjudicating international crimes against different protected groups and their members. In addition to the two Prosecutor's policy documentsboth of which explicitly address the interplay between phenomena of interesectional discrimination and mass crimes in the work of the ICC Prosecutor-the Al Hassan confirmation decision, CARII decisions and Ntaganda reparations order appear to betoken similarly positive developments towards pursuing more intersectional approach in the ICC case law. A critical and chronological assessment of the Court's intersectionality jurisprudence, however, suggests that it may be too early to say that these recent developments in Ic c case law are to be seen as an indication of an emerging trend to give greater and more conscious consideration to the intersectionality phenomena in its rulings. They may just as well simply represent occasional lucid moments in the Court's reasoning and pronouncement on this complex issue. It is accordingly proposed that the ICC should take intersectionality more seriously in both prosecution and adjudication of international crimes that involve multiple and
\end{abstract}


intersecting forms of discrimination. Having discussed what that might have looked like in some of the earlier ICC case law, the article turns to consider the prospects and space for the ICc to actually implement intersectionality in its future jurisprudence. It looks at potential practical implications of the proposed jurisprudential developments for the Court and for the field of international criminal justice more generally. Finally, the article also reflects on the eventual pitfalls and challenges that such a regular and consistent intersectionality-driven interpretation and application of international criminal law may present for the Court.

\section{Keywords}

intersectional discrimination - mass atrocities - protected groups - International Criminal Court - Office of the Prosecutor - ICC Chambers - ICC case law

\section{Introduction}

In 2014 the Office of the Prosecutor (OTP) adopted its Policy Paper on Sexual and Gender-Based Crimes that incorporates 'intersectionality' perspective as an important analytical tool in considering crimes directed specifically against women and girls or disproportionally affecting them. ${ }^{1}$ By promoting interpretation aligned with intersectional approach to underlying inequalities, the отP's policy paper pursues a more intersectionality-oriented treatment of sexual and gender-based crimes within the Court's legal and policy framework. It focuses on possible interaction of gender with ethnic, national, religious, political and economic factors or reasons for discrimination. Moreover, the policy paper highlights a critical interconnection and interplay that exist among such multiple factors and forms of discrimination and social inequalities in respect of atrocities under consideration.

This explicit and concrete commitment of the ICC Prosecutor (at least on paper) to properly address and engage with the phenomena of instersectionality when investigating and prosecuting complex situations and cases of discriminatory violence and abuse was reaffirmed two years later, in 2016, when the отP issued another policy document dealing with the effective

1 The Office of the Prosecutor, Policy Paper on Sexual and Gender-Based Crimes (2014), available online at www.icc-cpi.int/iccdocs/otp/policy_paper_on_sexual_and_gender-based_crimes-20_ june_2014-eng.pdf (accessed 2 January 2021), pp. 13, 16. 
investigation and prosecution of crimes against or affecting children. ${ }^{2}$ Here again, the отр committed itself to

Take steps to understand the significance of attributes like age and birth, and the degree to which they may give rise to multiple forms of discrimination and social inequalities, either alone or as they intersect with other factors, like race, ability or disability; religion or belief; political or other opinion; national, ethnic or social origin; gender, sex, sexual orientation; or other status or identity. ${ }^{3}$

As regards the crime against humanity of persecution, criminalised in Article $7(1)(\mathrm{h})$ of the Rome Statute, the oтP's Policy on Children accepts that, according to the diction 'other grounds that are universally recognized as impermissible under international law' and in light of Article 21(3) of the Rome Statute, acts targeting children on the grounds of birth or age may be charged as persecution. This is because both identities (birth and age) can be placed within the category of 'other grounds'. More importantly, this document acknowledges that children 'may also be persecuted on intersecting grounds, such as ethnicity, religion and gender'.

Clearly, both ОтР policy papers require that intersectional ideas and practices guide the ICC Prosecutor's understanding and consideration of mass atrocities. The present article takes the above policy directions of the отр on intersectional interpretation of mass crimes - notably those that target or affect particularly vulnerable groups such as women, girls and children - as a relevant reference point against which to assess the actual implementation of intersectionality and the development of expertise on key concepts related to it in the Court's earlier and more recent prosecutorial and judicial practice. Against this backdrop, one may wonder whether the recent Al Hassan confirmation decision, CARII decisions, as well as the Ntaganda reparations order (discussed in more detail below in the third section) as possible examples of the Court's fledgling intersectionality jurisprudence are to be perceived as positive and progressive developments as far as the application of intersectionality in international criminal law is concerned, or they are rather to be understood as being superficial and symptomatic of the broader malaise and deficiencies

2 The Office of the Prosecutor, Policy on Children (2016), available online at https://www.icc-cpi. int/iccdocs/otp/20161115_otp_icc_policy-on-children_eng.pdf (accessed 12 February 2021).

3 Ibid., p. 19.

4 Ibid., p. 24. 
regarding this subject matter, which are fairly typical of the Court's previous case law.

To address this meaningful question, the remainder of the article critically analyses the pertinent ICC case law, and in so doing, it distinguishes between two different scenarios: (1) prior to the OTP's adoption of the two key policy papers; and (2) following the issuance of the above policy documents by the ICC Prosecutor. Accordingly, the second and third sections of the article investigate - from a historical perspective - the ways in which the Court has prosecuted and adjudicated complex criminal cases involving or affecting various protected groups and their members. In so doing, they address racial, ethnic, religious, political, socio-economic and gender dimensions of the Court's rulings. By giving a chronological overview of such jurisprudential developments and achievements, these two sections aim to offer a sense of the evolving, albeit still nascent and arguably fragile, intersectionality-involving case law of the Court to date. The two sections moreover comment on a series of decisions from the past years in which the ICC failed to recognize and pay due regard to intersectional aspects of genocide, persecution and gender-based crimes, thus missing the opportunity to make use of the full potential of an intersectional inquiry into the root causes and effects of such atrocities.

Following a sample of non-implementation and limited implementation of an intersectionality-driven approach to multiple and overlapping factors and reasons for discriminatory targeting in the ICC case law, both sections also shed light on the sort of issues, merits and challenges an intersectional understanding of mass atrocities - as a prosecutorial and adjudicatory idea and practice of the Court - could bring to the table for prosecution and adjudication of core international crimes. The fourth and last section of the article concludes by highlighting the need for the Court's future case law and practice to build upon and further clarify key concepts and issues related to intersectionality-inclusive way of thinking in interpreting and applying international criminal law, while taking sufficient account of practical difficulties and restraints accompanying efforts for an increased implementation of intersectionality in prosecutorial and judicial decision making at the Court.

The next two sections discuss the selected cases before the Court that involve individuals allegedly responsible for sexual and gender-based atrocities committed against ethnic/religious groups and their members. In these cases, both gender and ethnic origin/religion were used as intersecting factors/reasons to 
target victims. Given that these punishable acts in fact targeted individuals because of their group identities, they demanded their intersectional consideration by the Court.

More particularly, the following two sections explore the instances in which the Court has (not) engaged with the issue of intersectionality when considering mass atrocities underlain by multiple inequalities. They briefly outline the factual background and the circumstances that gave rise to these cases and comment on the intersectionality-lacking reasoning and interpretations that were actually given by the Court. Significantly, they suggest how international criminal law should have been applied, interpreted and further developed by the ICC Prosecutor and judges in those circumstances, in order to more effectively protect the individuals with overlapping identities and to adequately redress the grievances and harms they suffered. By reflecting on the identified flaws and shortcomings in the Court's approach to the intersectionality conundrum, the article provides some further insights into the ways in which the prosecutorial and judicial treatment of mass abuses involving multiple and intersecting forms of discrimination could be improved through more confident and consistent implementation of an intersectional inquiry into the causes and effects of such a discriminatory violence. This analysis also includes a consideration of the role intersectionality could play in awarding possible remedies (reparations), as well as in contextualizing and assessing the gravity of such abuses, formulating charges and determining criminal sentence. All this can help us tease out the underlying reasons that may be at work and which may assist in explaining the prevailing uni-sectional or at best multi-sectional (this is, combined, additive or cumulative) approach of the ICC towards unique experiences of targeted or victimized individuals with multiple and intersecting identities.

As regards the ICC earlier jurisprudence on mass atrocities involving multiple and intersecting inequalities, several prominent cases associated with the situations in Darfur, Sudan (Harun and Kushayb, Al Bashir, Hussein), Kenya (Muthaura, Kenyatta and Ali), the Democratic Republic of the Congo (Lubanga, Mbarushimana) and the Republic of Côte d'Ivoire (Simone Gbagbo) demonstrate the Court's inadequate treatment of intersectional nature of the atrocities concerned.

From March 2003 to July 2008, there was a protracted non-international armed conflict in Darfur between the Government of Sudan (GoS) and several organized armed groups opposing the GoS. Following the attack on the El Fasher airport in April 2003, Omar Al Bashir and other high-ranking Sudanese political and military leaders came up with a common plan to carry out a counter-insurgency campaign against the opposing armed groups. A defining 
feature of that campaign was the unlawful targeting of the civilian population belonging largely to the Fur, Masalit and Zaghawa groups. In pursuing this campaign, GoS forces allegedly perpetrated crimes against humanity (including persecution), war crimes, and crimes of genocide through, inter alia, acts of rape and sexual violence against women and girls belonging mostly to these ethnic groups.

In all three cases related to the situation in Sudan-Harun and Kushayb, Al Bashir and Hussein - the ICC Pre-Trial Chamber found that there were reasonable grounds to believe that women and girls from the primarily Fur, Masalit and Zaghawa ethnic groups were victims of acts of rape perpetrated by members of the Sudanese armed forces and the Militia/Janjaweed. ${ }^{5}$ However, the Chamber (as well as the ICC Prosecutor) interpreted these crimes in a way that is more suggestive of a unisectional understanding of discriminatory targeting than genuinely intersectional approach advanced in this article. Conceptually, the Court's reasoning in these early cases seems to focus on either ethnic elements of such punishable acts (for instance, acts of rape, among other criminal acts, were committed against members of the targeted ethnic groups) or their sexual character (for example, rape of civilian women and girls belonging primarily to the Fur, Masalit and Zaghawa population).

Another fine illustration of how multiple and intersecting identities of individuals targeted or affected by mass atrocities often overlap and interact is the case of Muthaura, Kenyatta and Ali. All three defendants were accused of being responsible for crimes against humanity perpetrated in the context of the 2007-2008 post-election violence taking place in or around Nakuru and Naivasha in Kenya and having the form of a widespread and systematic attack against the non-Kikuyu population (mostly belonging to Luo, Luhya and Kalenjin ethnic groups). These atrocities included persecution on political grounds perpetrated through murder, rape and other forms of sexual violence. They also reflected intense ethnic tensions and pervasive gender

5 ICC, The Prosecutor v. Omar Hassan Ahmad Al Bashir, ICC-02/o5-01/og, Pre-Trial Chamber I, Decision on the Prosecution's Application for a Warrant of Arrest against Omar Hassan Ahmad Al Bashir (Public Redacted Version), 4 March 2009, para. 108, and Second Decision on the Prosecution's Application for a Warrant of Arrest (Public Document), 12 July 2010, para. 30; ICC, The Prosecutor v. Hussein, ICC-02/05-01/12, Pre-Trial Chamber I, Public redacted version of 'Decision on the Prosecutor's application under article $5^{8}$ relating to Abdel Raheem Muhammad Hussein', 1 March 2012, para. 13(ix); ICC, The Prosecutor v. Harun, ICC02/05-01/07, Pre-Trial Chamber I, Warrant of Arrest for Ahmad Harun (Public Document), 27 April 2007, Counts 13, 14, 42, 43 and 46; ICC, The Prosecutor v. Kushayb, ICC-02/o5-01/o7, Pre-Trial Chamber I, Warrant of Arrest for Ali Kushayb (Public Document), 27 April 2007, Counts 13, 14, 42, 43, 46 and 47 . 
discrimination within Kenyan society. Rather than formulating the charges of persecution on intersecting grounds, however, the ICC Prosecutor narrowed down the scope of interpretation and application of the law of persecution to a single-ground discrimination, this is unequal treatment on the grounds of 'political affiliation' alone.

The complexity of the persecutory intent in this particular case could have been better captured and explained if the ICc Prosecutor applied intersectionality analysis, thus reflecting the discriminatory purpose in the charges by including cumulative grounds of persecution (additive discrimination). ${ }^{6}$ The Prosecutor could also have chosen to approach the issue of intersectionality by interlinking grounds of persecution in indictments, thereby making possible for the pre-trial judges to consider persecution 'without necessarily delinking these grounds. ${ }^{7}$ This could include, for example, the Prosecutor's separate analysis of each of the relevant reasons for discrimination (political affiliation, ethnic origin, as well as gender) and explanation of how the persecutory acts were composed of all these different factors/identities as essential elements of discriminatory targeting. Such an intersectional approach to contextualizing and analyzing the crime of persecution would have helped the ICC Prosecutor and Pre-Trial Chamber better understand the unique nature of these atrocities as committed in the particular Kenyan context, and also establish their complex links with underlying social factors and reasons for discriminatory violence.

Importantly, the ICC Prosecutor correctly observed that criminal acts of forcible circumcision and penile amputation committed against Luo men amounted to sexual violence as they were intended to attack their gender identity in their society and thus severely damage their virility. ${ }^{8}$ In light of this interpretation put forward by the Prosecutor, it seems somewhat surprising that pre-trial judges, when confirming charges against Muthaura and Kenyatta, disregarded an important sexual dimension of these atrocities and simply requalified them from 'other forms of sexual violence' to 'other inhumane acts'. ${ }^{9}$ The Pre-Trial Chamber explained this requalification with the following words:

6 A. Martin Beringola, 'Intersectionality: A Tool for the Gender Analysis of Sexual Violence at the ICC', 9(2) Amsterdam Law Forum (2017) 84-109, p. 103.

7 V. Oosterveld, 'Gender, Persecution, and the International Criminal Court: Refugee Law's Relevance to the Crime Against Humanity of Gender-Based Persecution', 17(49) Duke J. Comp. Int. Law (2006) 49-89, p. 86.

8 ICC, The Prosecutor v. Muthaura, Kenyatta and Ali, ICC-01/o9-02/11, Pre-Trial Chamber II, Public Redacted Version of Decision on the Confirmation of Charges Pursuant to Article 61 $(7)$

(a) and (b) of the Rome Statute, 23 January 2012, para. 264.

9 Ibid., para. 266. 
the evidence placed before it does not establish the sexual nature of the acts of forcible circumcision and penile amputation visited upon Luo men. Instead, it appears from the evidence that the acts were motivated by ethnic prejudice and intended to demonstrate cultural superiority of one tribe over the other. ${ }^{10}$

Evidently, both the Prosecutor and the pre-trial judges used a narrow uni-sectional approach to considering persecutory acts that were actually conditioned by intersecting gender and ethnic forms of discrimination which ultimately contributed to the specific criminal context. By narrowing the phrasing and interpretation down to only gender dimension (in case of the ICC Prosecutor) or only ethnic dimension (in case of the Pre-Trial Chamber) of violent acts, the Court missed the opportunity to recognize the intersectional reality of these crimes and consequently their greater severity because of aggravated nature of combined gender and ethnic discrimination. In addition, there was also the third facet of inequality to these crimes that the ICC Prosecutor and pre-trial judges seem to have completely overlooked, namely that of political affiliation. To properly comprehend and respond to all three kinds of discrimination underlying the acts of persecution and their unique interaction, the Prosecutor and judges should have considered, for example, in what manner ethnicity intersected on the one hand with gender and on the other hand with political affiliation, and whether such an intersectional discrimination constituted a crucial aspect of the persecution. Another important issue for the Prosecutor and pre-trial judges to look at should also be whether the facts and evidence available demonstrated that the intersection of the three protected grounds of discrimination behind the atrocities in question compounded the gendered harms.

The next case in which the ICC was either unable or unwilling to identify and comprehend issues of intersectionality in respect of mass crimes under examination (sexual abuses against young girls) is Lubanga. These abuses were grounded in the intersection of gender and age discrimination. This intersection of gender and young age as reasons for discriminatory targeting greatly enhanced the likelihood of girls' exposure to sexual abuses in light of their high vulnerability during the armed conflict. It was precisely the lack of gender analysis in the Prosecutor's assessment that somehow obscured an intersectional character of the gender-based crimes reflected in their extreme gravity. Since the ICC Prosecutor from the outset failed to include in his analysis the

$10 \quad$ Ibid. 
gender dimension of discriminatory targeting, the Court could not properly assess this more severe form of criminality in order to establish individual criminal responsibility and to order adequate reparations. ${ }^{11}$

There are in fact two main reasons why such an assessment of the role and impact of gender-based inequality as part of overall contextual analysis of the alleged crimes would have been of particular value in this concrete case. ${ }^{12}$ First, the analysis of gender dimensions of these abuses would have assisted the Prosecutor in grasping the significance of multiple reasons for discriminatory targeting that made children, and girls in particular, vulnerable within the Union des Patriotes Congolais/Forces Patriotiques pour la Libération du Congo (UPC/FPLC). The second point of using intersectionality is that such an understanding would have made possible for the Prosecutor to examine in what way and to what extent the multiple social factors of discriminatory violence actually intersected. By means of intersectional analysis, the ICC Prosecutor could have ascertained whether the interconnection between intersecting grounds of discrimination (gender, age, and the status of soldier) gave rise to a heightened risk and particular vulnerability of girl soldiers.

Intersectional account of discriminatory intent underpinning sexual abuses in Lubanga would have enabled the Prosecutor to adopt a well-informed decision necessary for better appreciation of the gravity elements such as manner of commission of the atrocities, their essential characteristics and their adverse effects. In the absence of an intersectionality-based approach to age and gender inequalities and germane social factors, the Prosecutor was not able to fully appreciate a much greater vulnerability of girl soldiers than boy soldiers. Such a lack of understanding of intersectionality of sexual abuses resulted in the Prosecutor's inadequate assessment of the atrocities' level of gravity and of the access to justice and remedy for victims. Indeed, this led the Prosecutor to narrowing the scope of the criminal behaviour, obscuring the multiple harms suffered by girl soldiers, generalizing the impact of discriminatory violence, and ultimately precluding victims of sexual and gender-based crimes from being awarded equitable and proportional reparations. ${ }^{13}$

The lack of intersectionality-sensitive approach by the Court to the complex and multi-faceted character of atrocities under consideration can moreover be observed in another case related to the situation in the Democratic Republic of Congo (DRC) - the case of Mbarushimana. There was a non-international armed conflict taking place throughout 2009 in the North and South Kivus,

11 Beringola, supra note 6, p. 94.

12 Ibid.

$13 \quad$ Ibid., p. 96. 
in the DRC. This conflict involved the armed forces of the Government of the DRC (supported also by Rwandese forces and the forces of the United Nations Mission in the Democratic Republic of Congo) and the opposing organized armed group, the Forces Démocratiques pour la Libération du Rwanda-Forces Combattantes Abacunguzi (FDLR). The atrocities committed by members of FDLR included rapes and other forms of sexual violence, as well as persecution on the grounds of gender. Callixte Mbarushimana who was Executive Secretary of the FDLR was alleged to have substantially contributed to these crimes and thus to bear criminal responsibility for them. While initially (in his Application for a Warrant of Arrest $)^{14}$ the ICC Prosecutor had correctly identified both gender and political affiliation as overlapping reasons for discriminatory atrocities involving acts of persecution, he later (in the Document Containing the Charges) $)^{15}$ accused the defendant merely of politically motivated persecution, thus narrowing his consideration to single-ground analysis.

Articulating the crime of persecution as having only political dimension may eventually have had some influence on the subsequent developments in this particular case. Indeed, the intersectionality-centred analysis could have helped the Prosecutor more clearly identify the relevant contextual element of the attack of FDLR against civilians. More particularly, intersectionality perspective might have helped the ICC Prosecutor more accurately assess and better capture the brutal and large-scale character of persecutory violence motivated by intersectional (gender and political affiliation-based) discrimination. Clarifying the multi-faceted nature and impact of overlapping political and gender dimensions of the attack and accordingly the victims' multiple vulnerabilities and harms would have enabled the Prosecutor to shed some additional light on the organisational policy element (within the meaning of Article 7 of the Rome Statute) of persecutory campaign and thus highlight its extreme gravity.

In its decision on the confirmation of charges, however, the ICC Pre-Trial Chamber did not find substantial grounds to believe that crimes against humanity were perpetrated by the FDLR troops. Therefore, the Pre-Trial Chamber could not proceed with its examination of persecution as one of the underlying crimes against humanity. This situation could possibly have been

14 ICC, The Prosecutor v. Mbarushimana, ICC-01/04, Pre-Trial Chamber I, Public Redacted Version of the Prosecution's Application under Article 58, 20 August 2010, pp. 7, 17 and 36 (paras 95 and 97).

15 ICC, The Prosecutor v. Mbarushimana, ICC-01/04-01/10, Pre-Trial Chamber I, Public Redacted Version of Decision on the confirmation of charges, 16 December 2011, Dissenting opinion of Judge Sanji Mmasenono Monageng, para. 36. 
remedied had the ICC Prosecutor formulated the charges of persecution in a manner that mirrors its compound discriminatory nature. For example, the Prosecutor could have chosen to charge the crime of persecution cumulatively, this is on political and gender grounds combined (additive discrimination). An alternative and more sophisticated way of approaching the issue of intersectionality would be to charge such persecutory acts on one ground of discrimination (political affiliation) while reflecting its overlap/intersection with the other discriminatory ground (gender). Preferably, the Prosecutor should have consider intersectionality in phrasing the charges, thereby ensuring that the multi-faceted nature of the harms, victims' vulnerabilities and effects were not left unaddressed. ${ }^{16}$

The post-elections violence in Côte d'Ivoire between 28 November 2010 and 12 April 2011, in the context of which pro-Gbagbo forces attacked the civilian population in Abidjan and in the West of the country, is yet another case in point. During the violence, Members of specific ethnic or religious groups who were deemed to be supporters of the opponent presidential candidate Alassane Outtara were particularly targeted. In the wake of these atrocities, the ICC issued a Warrant of Arrest for Simone Gbagbo who is suspected of having committed certain crimes against humanity, including rape and other sexual crimes, and also persecution on political, ethnic or religious grounds. ${ }^{17}$ Here again, while the Court rightly observed multiple and intersecting dimensions of targeted discriminatory violence at this initial stage of a criminal proceeding, it remains to be seen what further steps (if any) with regard to the intersectionality issue it will take once the suspect is arrested and transferred to the Hague for a possible trial.

In its 'pre-Отр Policy Papers' case law examined above, the Court could have approached the issue of intersectionality more directly, decisively and comprehensively during all stages of the prosecution and trial (investigation, formulation and confirmation of charges, trial and sentencing, and providing remedies for victims). This would have made possible for the Court to unravel and more accurately define and express the complex, compound and multi-faceted reality, as well as aggravated circumstances of interconnected political, ethnic, religious, sexual and other forms of violence that are typically underlying reasons or root causes for mass atrocities. Moreover, such a holistic and contextual comprehension of intersectional violence by the Court could have ensured that more people of different protected characteristics were represented and

16 Beringola, supra note 6, p. 108.

17 ICC, The Prosecutor v. Simone Gbagbo, ICC-02/11-o1/12, Pre-Trial Chamber III, Warrant of Arrest for Simone Gbagbo, Gbagbo, 29 February 2012, para. 5 . 
protected against violent targeting and crimes, that discriminatory purpose of these violent acts was more harshly punished, and that their particularly harmful effects were adequately addressed and repaired.

Some interesting 'post-oTp Policy Papers' jurisprudential developments with regard to recognising multiple and intersecting forms of discriminatory targeting in the context of mass crimes occurred in four cases before the Court arising from the situations in the Democratic Republic of the Congo (Ntaganda), Mali (Al Hassan) and the Central African Republic II (Yekatom and Ngassona and Said).

In Ntaganda, the defendant was accused of crimes committed in the context of a non-international armed conflict between the Union des Patriotes Congolais (UPC) with its military wing, the Forces Patriotiques pour la Libération du Congo (FPLC), and the Ugandan armed forces (UPDF), as well as between the UPC/FPLC and opposing organised armed groups, specifically the APC and its allies, the FNI/FRPI and Lendu fighters, in the Ituri district of the DRC, between August 2002 and December 2003. ${ }^{18}$ During this conflict the UPC/ FPLC conducted a widespread and systematic attack against the civilian population between August 2002 and May 2003. These crimes were committed pursuant to a common plan to drive out all the Lendu from the localities targeted during the course of the UPC/FPLC military campaign against the RCD-Kisangani, subsequently called the RCD-K/ML (a rebel movement supported by Uganda), and to prevent them from returning to the assaulted localities. Within this context, the ICC Trial Chamber found that the UPC/FPLC committed a series of crimes during both the First Operation, in the Banyali-Kilo collectivite in November/December 2002, and the Second Operation, in the Walendu-Djatsi collectivité in February/March 2003. This attack resulted in mass atrocities particularly targeting Lendu ethnic community. Bosco Ntaganda, who was the Deputy Chief of Staff of the UPC/FPLC and commander of operations of the FPLC, was consequently found liable as a direct perpetrator for parts of the charges of some of these crimes, including crime against humanity of ethnicity-based persecution against members of Lendu.

It is important to note that the interpretation of the crime of persecution in the Ntaganda judgment exhibits some signs of the Court slowly moving

18 ICC, The Prosecutor v. Bosco Ntaganda, ICC-01/04-02/o6, Trial Chamber vi, Reparations Order, 8 March 2021, paras 25-27. 
from its uni-sectional understanding of mass atrocities typical of its previous jurisprudence towards more multisectionally-oriented consideration of such crimes. As the Court spelled out in this judgment, one prohibited ground of discrimination as a reason for the acts of persecution will be sufficient, but 'a combination of more than one may equally form the basis for the discrimination.19 Indeed, with this interpretative approach the ICC Chamber gave preference to the multiple discrimination-based treatment of mass atrocities, though the trial judges' conception of such compound forms of discrimination underlying the crimes in question seems to be closer to combined (this is, additive or cumulative) than their truly intersectional understanding.

In its recent reparations order issued in Ntaganda, the ICC Trial Chamber showed even greater intersectionality awareness, highlighting that victims' multiple and intersecting identities constituted an essential element of certain sexual and gender-based atrocities that were committed against them. ${ }^{20}$ Unlike in its previous case law on reparations (Al Mahdi, Katanga, Lubanga), this time the Court was surprisingly quick in taking note of a convergence of factors of discrimination reflected through the patterns and forms of the atrocities. As the Trial Chamber correctly articulated, reparations for multiple and diverse harms that victims of intersectional targeting suffered need to take into account the fact that the intersection of different factors of discrimination increased the victims' comparative disadvantages and risks. Moreover, such greater disadvantages and increased risks related to certain vulnerable groups of individuals (for example, child victims and especially girl victims). Thus, Lendu male and female victims of ethnic persecution and of sexual abuses shared specific factors of discrimination, but they also suffered a specific form of discrimination because of the confluence of all these factors and, in some cases, because Lendu women were pregnant, because they were girls, or because they were girls and pregnant. In this regard, it is important to stress that pregnancy may amount to a situation of particular vulnerability and, in some cases of discriminatory targeting, pregnancy may result in a differentiated violations and harms.

Another important step forward by the Court in paying greater attention to the issue of intersectionality in the context of reparations for multiple harms suffered by victims of discriminatory violence is expressed through the Chamber's repeated commitment in the Ntaganda reparations order to a gender-inclusive perspective on the design and implementation of reparations.

19 ICC, The Prosecutor v. Bosco Ntaganda, ICC-01/04-02/o6, Trial Chamber VI, Judgment with public Annexes A, B, and C, 8 July 2019, para. 1009.

20 Supra note 18. 
The Court already emphasized on previous occasions that reparations are to be formulated and applied in a gender-inclusive and sensitive manner. ${ }^{21} \mathrm{~A}$ gender-sensitive consideration to reparations involves the requirement to address the views, experiences, and needs of all individuals (irrespective of their gender and age) with diverse gender identities and sexual orientation, while seeking to unravel and understand the complexity and intersectionality of their experiences and to retain a relational and holistic focus. The Trial Chamber moreover noted that due consideration should be given to the existence of previous gender disparities and power imbalances, as well as the differentiated effect of harm based on the victim's gender expression/ gender identity/sexual orientation. In the words of the Chamber, 'a gender-inclusive and sensitive perspective should integrate intersectionality as a core component'.22

This highly important judicial statement implies that it is necessary: (1) to adequately identify and measure unique and specific harms that victims of mass atrocities may have suffered because of their gender's interaction (this is, intersection) with other prohibited factors and reasons for discriminatory targeting, and (2) to design appropriate types and modalities of reparations that reflect and effectively address such complex and multifaceted harms. ${ }^{23}$ Equally important, due regard should also be given to the phenomena of intersectionality when it comes to the implementation of reparations, in order to eschew reinforcing any type or form of discrimination or contributing to the marginalisation of discriminated groups. ${ }^{24}$ Such an intersectionality-inspired approach to reparations will ensure that victims' redress for the harms suffered is more adequate, appropriate and efficient.

The commission of mass atrocities on the discriminatory basis is often closely intertwined with an abuse of power and domination exercised by perpetrators. In committing such atrocious crimes perpetrators usually take advantage of the vulnerability of the victims and they discriminate against them. This is particularly notable, for example, in situations and cases involving sexual abuses

21 ICC, The Prosecutor v. Thomas Lubanga Dyilo, ICC-o1/o4-o1/o6, Trial Chamber I, Decision establishing the principles and procedures to be applied to reparations, 7 August 2012, para. 243; ICC, The Prosecutor v. Germain Katanga, No. ICC-01/o4-01/o7, Trial Chamber II, Order for Reparations pursuant to Article 75 of the Statute, 24 March 2017, para. 310; ICC, The Prosecutor v. Ahmad Al Faqi Al Mahdi, ICC-o1/12-01/15, Trial Chamber viII, Reparations Order, 17 August 2017, para. 34 .

22 Supra note 18, para. 6o.

23 Supra note 18, para. 61.

24 Supra note 18 , para. 62. 
against children where such abuses emerge from the dynamics of power and oppression between powerful perpetrators and vulnerable victims.

When designing and implementing reparations it is thus critical for the Court to ensure that reparations properly address any underlying and overlapping systems of power, oppression and injustices and that they do not replicate, perpetuate or reinforce previous structural inequalities or discriminatory practices that coexisted next to each other (and possibly intersected with each other) prior to the commission of the atrocities and which denied victims equal access to their rights. ${ }^{25}$ In other words, reparations must be implemented in an intersectionality (this is, gender, socio-economic and culturally) sensitive and responsive manner which does not perpetuate or aggravate any traditional or (pre-)existing structure of inequalities and which efficiently addresses any situation of (intersectional) discrimination preventing equal treatment and equal opportunities to victims. This is the so-called 'transformative' role that reparations need to assume while seeking to serve the purposes of both restorative as well as corrective justice. The Court should strive to generate such transformative and rectification effects of reparations through their design, implementation and impact, thereby fostering the necessary structural changes, dismantling (multiple and overlapping) inequalities, stereotypes, and discriminatory practices that may have contributed to create and promote the contexts and conditions for mass atrocities to occur. ${ }^{26} \mathrm{In}$ determining the scope and reach of transformative dimensions of reparations, the Court should focus on tackling social rejection and exclusion, eliminating discrimination and marginalisation by facilitating participatory practices and processes while also challenging unequal power relations. ${ }^{27}$

In particular, in ordering reparations the Court needs to avoid to every extent possible further stigmatisation and secondary discrimination of the victims as well as intensifying discrimination by their families and communities. ${ }^{28}$ This

25 This, in effect, means that, in the context of structural discrimination and violence, the concept of restitutio in integrum (integral reparation)-which entails, inter alia, the re-establishment of the previous situation-needs to be adjusted in the sense that reparations are designed to change this situation, so that their effect is of both restitution and rectification. As a result, re-establishment of the same structural context of violence and discrimination cannot be accepted as part of awarding reparations. Inter-American Court of Human Rights, Gonzalez et al v. Mexico (Cotton Field Case), Preliminary Objection, Merits, Reparations, and Costs, Judgment, 16 November 20o9, para. 450.

26 Supra note 18 , para. 94.

27 Supra note 18 , para. 95 .

28 ICC, The Prosecutor v. Thomas Lubanga Dyilo, ICC-01/04-01/o6, Trial Chamber I, Decision establishing the principles and procedures to be applied to reparations, 7 August 2012, para. 192. 
may require the Court to exclude from implementing its reparations - even if they play a culturally paramount role in awarding such reparations - when these are historically discriminatory, especially against women and girls. ${ }^{29}$ In other words, wherever possible, reparations should reflect local cultural and customary practices unless these are unjust, discriminatory, exclusive or prevent equal opportunities to victims of mass atrocities. ${ }^{30}$ Moreover, the Court - when deciding on reparations - should seek to ensure that reparations do not trigger or exacerbate potential or existing ethnic and/or religious tensions within communities and that individual awards do not have adverse or discriminatory consequences for victims, their families and their communities.

As regards the type of reparations, in Ntaganda the Court decided to award collective reparations with individualised components, since they may provide a more holistic approach to the multi-faceted harm suffered by the victims of mass atrocities such as ethnicity-based persecution and sexual and gender-based crimes. ${ }^{31}$ Presumably, physical or psychological harm, such as that caused by rape, sexual slavery and persecution can be better repaired by awarding collective reparations. Moreover, this type of reparations is more likely to ensure a more efficient, prompt, and practical approach when a large number of victims of these crimes are to be expected. In the light of the foregoing, collective reparations with individualised components appear the most appropriate approach to addressing and remedying harms and injustices caused by mass crimes, including those resulting from multiple and intersecting forms of discrimination.

Al Hassan offers another good example of how intersectionality operates in the context of mass atrocities committed in a situation of armed conflict. In January 2012, a non-international armed conflict broke out in Mali. From the beginning of April 2012 to 17 January 2013, the city of Timbuktu was allegedly under the control of the armed groups Al-Qaida in the Islamic Maghreb ("AQIM") and Ansar Eddine, a primarily Tuareg movement associated with

29 ICC, The Prosecutor v. Ahmad Al Faqi Al Mahdi, ICC-01/12-01/15, Trial Chamber viII, Reparations Order, 17 August 2017, para. 148.

30 ICC, The Prosecutor v. Bosco Ntaganda, ICC-01/04-02/o6, Trial Chamber vi, Reparations Order, 8 March 2021, para. 9o; ICC, The Prosecutor v. Germain Katanga, No. ICC-o1/o4-o1/o7, Trial Chamber II, Order for Reparations pursuant to Article 75 of the Statute, 24 March 2017, para. 268; ICC, The Prosecutor v. Ahmad Al Faqi Al Mahdi, ICC-01/12-01/15, Trial Chamber VIII, Reparations Order, 17 August 2017, para. 34; ICC, The Prosecutor v. Thomas Lubanga Dyilo, ICC-01/04-01/o6, Appeals Chamber, Judgment on the appeals against the "Decision establishing the principles and procedures to be applied to reparations" of 7 August 2012 with amended order for reparations (Annex A) and public annexes 1 and 2, 3 March 2015, Order for Reparations (amended), para. 47. 
AQIM. During that period, $\mathrm{Mr} \mathrm{Al}$ Hassan is alleged to have contributed to the perpetration of particularly serious crimes, including religious and gender-based persecution by those armed groups as part of a widespread and systematic attack against the civilian population of Timbuktu. As a member of Ansar Eddine and de facto chief of the Islamic police, he is also alleged to have participated in the policy of forced marriages which victimized the female inhabitants of Timbuktu and led to repeated rapes and sexual enslavement of women and girls. In July 2012, the Government of Mali referred the situation in Mali since January 2012 to the Court. Having conducted a preliminary examination of the situation, the ICC Prosecutor concluded, in March 2013, that there is reasonable basis to believe that international crimes under the Court's jurisdiction have been committed in Mali since January 2012, and decided to open an investigation in this situation. ${ }^{32}$

In March 2018, the ICC Pre-Trial Chamber issued a warrant of arrest for Mr Al Hassan in which it noted that, in Timbuktu and its region, civilians - women and girls in particular-were targeted because they were perceived as not abiding by the religious vision held by Ansar Eddine and AQIM. ${ }^{33}$ Violent acts and crimes committed by members of Ansar Eddine/AQMI reflected deep-seated and pervasive discriminatory practices and abusive attitude towards female members of Malian society in that they imposed disproportionate sanctions against women as well as sanctions involving gender-based violence. Such gender-specific sanctions also involved rapes committed against women in detention in the context of forced marriages. Gender-based persecution and sexual violence that female victims suffered led them to losing their social status among the civilian population of Timbuktu. They were marginalised in the local society and also stigmatised within their families. The Icc Pre-Trial Chamber thus found in its decisions on the confirmation of charges brought against $\mathrm{Al}$ Hassan that there are substantial grounds to believe that the accused is responsible for these crimes against humanity, including rape, sexual slavery, forced marriages and persecution.

More significantly, the pre-trial judges concluded in their confirmation decision that gender-based violence and sexual abuse against women in this particular case may also have been driven by considerations linked to their skin

32 ICC, Case Information Sheet, available online at www.icc-cpi.int/CaseInformationSheets/ al-hassanEng.pdf (accessed 26 March 2021).

33 ICC, The Prosecutor v. Al Hassan Ag Abdoul Aziz Ag Mohamed Ag Mahmoud, ICC-o1/12-o1/18, Pre-Trial Chamber I, Public redacted version of Decision on the Prosecutor's Application for the Issuance of a Warrant of Arrest for Al Hassan Ag Abdoul Aziz Ag Mohamed Ag Mahmoud, 22 May 2018, para. 63. 
colour. As a result, dark-skinned women were more frequently and harshly targeted than others. According to some witnesses, men with dark skin were also more often victims of persecution than those with bright skin. ${ }^{34}$ The Pre-Trial Chamber moreover observed that the elderly, pregnant women and children were treated in particularly violent manner. ${ }^{35}$ These acts of discriminatory violence and persecution were committed against civilians on the basis of their religion, but also on grounds of their race (skin colour) and gender (as women and girls within these identifiable groups or collectives were subject to stricter rules and attacked for the slightest alleged violations of those rules). Such a persecution was motivated by and based on multiple and intersecting discriminatory grounds (religion, race and gender), and was committed through a number of criminal acts, including torture, cruel treatment, sexual abuses and gender-based crimes (rape, sexual slavery, forced marriages), the directing of attacks against monuments dedicated to religion, the passing of sentences without previous judgment pronounced by a regularly constituted court, and other inhumane acts. ${ }^{36}$

The last two cases I wish to discuss here both relate to the situation of the Central African Republic (CAR) II. Between September 2013 and December 2014, there was a non-international armed conflict taking place in the territory of the CAR between two organised armed groups - the Anti-Balaka and the Seleka. During the hostilities, both sides perpetrated s series of mass atrocities, including crimes against humanity and war crimes, in the context of a widespread and systematic attack against the civilian population and those perceived to be the political opponents. The Seleka targeted the civilian population based on religious grounds (Christians were considered to support the former government), affiliation with the former government (such as government employees), ethnicity (the Gbaya tribe), or location (specific neighbourhoods were considered as generally being supportive of the former government). The Seleka accused the persons falling within these categories of supporting the former government or planning a coup against the Seleka in order to justify persecuting, harassing, raping and sexually abusing, detaining or torturing them. ${ }^{37}$

34 ICC, The Prosecutor v. Al Hassan Ag Abdoul Aziz Ag Mohamed Ag Mahmoud, ICC-01/12-01/18767-Corr-Red, Pre-Trial Chamber I, Version publique expurgée du Rectificatif de la Décision portant modification des charges confirmées le 30 septembre 2019 à l'encontre d'Al Hassan Ag Abdoul Aziz Ag Mohamed Ag Mahmoud, 23 avril 2020, 8 May 202O, para. 702.

35 Ibid., para. 704.

36 Ibid., para. 707 .

37 ICC, The Prosecutor v. Mahamat Said Abdel Kani, ICC-01/14, Public Redacted Version of 'Warrant of Arrest for Mahamat Said Abdel Kani', 17 February 2021, para. 12. 
On the other hand, the Anti-Balaka conducted a widespread and systematic attack against the Muslim civilian population in western CAR in retribution for the crimes and the abuses committed by the Seleka. Based on their religious or ethnic affiliation, Muslims were perceived as collectively responsible for, complicit with or supportive of the Seleka. From early 2013 onwards, anti-Muslim sentiments and inflammatory rhetoric were openly expressed, also through the means of television and radio, inciting hatred and violence against Muslim civilian communities and other perceived supporters of the Seleka. ${ }^{38}$ Following that, Muslim population was exposed to escalating retributive sectarian violence by Anti-Balaka groups. The Anti-Balaka's campaign also involved developing an organisational criminal policy of violent targeting the Muslim civilian population (on religious, national and ethnic grounds) and those perceived to have supported the Seleka in western CAR. As a result of this campaign, Muslims and the alleged supporters of the Seleka suffered various grave crimes with a strong ethnic/religious overtone, including attacks against the civilian population, displacement, forcible transfer or deportation, summary executions, killings, persecution, torture and cruel treatment, mutilations, sexual offences, destruction of Muslim property and religious buildings (mosques), as well as routine pillaging of Muslim houses and shops. ${ }^{39}$

In May 2014, the Central African authorities referred the situation concerning crimes allegedly committed in CAR since 1 August 2012 to the ICC. In September 2014, the ICC Prosecutor opened a second investigation in CAR regarding crimes allegedly committed since 2012. The Court issued a warrant of arrest for Alfred Yekatom in November 2018 and for Patrice-Edouard Ngaïssona in December 2018. In December 2019, the ICC Pre-Trial Chamber unanimously adopted a decision partially confirming the charges of war crimes and crimes against humanity brought by the ICC Prosecutor against both suspects and committed them to trial. The Pre-Trial Chamber thus confirmed the charges against Mr Yekatom of having committed crimes against humanity, including for the severe deprivation of the fundamental rights of Muslim persons, by targeting them on political, ethnic and/or religious grounds. In addition to the charges of the acts of (political, ethnic and/or religious) persecution against Muslim population, in respect of Mr Ngaïssona the Pre-Trial Chamber also

38 ICC, The Prosecutor v. Alfred Yekatom, ICC-o1/14-o1/18, Pre-Trial Chamber II, Public Redacted Version of "Warrant of Arrest for Alfred Yekatom", 17 November 2018, para. 7; ICC, The Prosecutor v. Patrice-Edouard Ngaïssona, ICC-01/14-02/18, Pre-Trial Chamber II, Public Redacted Version of "Warrant of Arrest for Patrice-Edouard Ngaïssona", 13 December 2018, para. 7 . 
confirmed the charges of rape of a woman (both as a war crime and as a crime against humanity)..$^{40}$ This added to mass atrocities the fourth layer of intersectionality consisting of gendered violence and oppression.

In January 2019, a single pre-trial judge issued a warrant of arrest, under seal, against the third person suspected of crimes against humanity (torture, persecution on multiple and intersecting grounds; imprisonment or other severe deprivation of liberty, enforced disappearance, other inhumane acts) and war crimes (torture and cruel treatment) allegedly committed in Bangui, Central African Republic in 2013 - Mahamat Said Abdel Kani. Mr Said is alleged to have been a Seleka commander and thus criminally responsible for the commission of the above atrocities. The single ICC judge found reasonable grounds to believe that from at least March 2013 until at least January 2014, a widespread and systematic attack was conducted by members of the Seleka against the civilian population and those perceived to be collectively responsible for, complicit with or supportive of the former Bozizé government and, later, of the Anti-Balaka. As part of this Seleka's organisational policy, the civilian population was targeted through multiple criminal acts of murder, torture, rape, persecution on political, ethnic and religious grounds, imprisonment, and pillaging of houses belonging to non-Muslims and others perceived to be complicit with or supportive of the Bozizé government and, later, of the Anti-Balaka. ${ }^{41}$

In the three most recent cases discussed above-Al Hassan, Yekatom and Ngaïssona and Said - the suspects were accused of having committed persecution and sexual abuses on two or more protected grounds combined (for example, political, ethnic and religious affiliation, as well as gender). Such a more nuanced legal qualification by the ICC Prosecutor of discriminatory violence targeting or affecting protected and vulnerable groups provides ICC judges with a new golden opportunity to make a substantial jurisprudential contribution to the law of core crimes that implicate intersectionality. The judges can thus considerably advance the Court's intersectionality jurisprudence through deliberating and pronouncing on: (1) how, in a particular case, gender, race, ethnicity, religion and political affiliation as underlying discriminatory reasons for the relevant crimes were interlinked; (2) the scope, mode and extent to which multi-faceted and compound forms of discrimination overlapped and interacted with each other in the context of a given conflict

40 ICC, The Prosecutor v. Alfred Yekatom and Patrice-Edouard Ngaïssona, ICC-01/14-01/18, Pre-Trial Chamber II, Corrected version of 'Decision on the confirmation of charges against Alfred Yekatom and Patrice-Edouard Ngaïssona', 14 May 2020, para. 241.

41 ICC, The Prosecutor v. Mahamat Said Abdel Kani, ICC-01/14, Public Redacted Version of 'Warrant of Arrest for Mahamat Said Abdel Kani', 17 February 2021, para. 17. 
or violence; and (3) the actual impact and implications of the intersectionality phenomena in each particular criminal case for consideration of such issues as the gravity assessment, the contextualization of crimes, the identification and interpretation of applicable law, the determination of criminal sentence, and the provision of adequate reparations for victims. Most notably, the ICC Chambers should take account of particular vulnerability of women, girls and aged people inherent in their situation as civilians coming from or living in the areas affected by the brutalities.

This article has explored - from a chronological point of view-the steps the Court has taken in implementing intersectionality perspective in its case law to date, using the отр policy papers on sexual and gender-based crimes and crimes against children as a main point of reference to guide us in our assessment. In relation to its earlier jurisprudence (this is, jurisprudence before the adoption of the two policies), there appears to have been a general failure on the part of the Court to engage with the phenomena of intersectionality. In its prosecutorial and judicial practice, the Court mostly pursued a uni-sectional approach to enforce international criminal law. It tended to consider the protected characteristics as reasons for discriminatory targeting and persecution separately and independently from one another, thus not being able to fully appreciate the impact of their interoperability on the patterns of criminal conduct and ensuing mass atrocities and harms they implicate.

As regards its more recent case law, it seems that the Court has made some initial efforts to better understand and more readily apply intersectionality, mostly through its recognition that certain segments and groups of populations (such as women belonging to certain ethnic groups or dark skinned men of a 'wrong' religion and political affiliation) are particularly targeted in the context of armed conflict. However, this elementary comprehension and rather limited application of intersectionality in the Prosecutor's charges and judicial decisions need to be further elaborated on in the Court's future jurisprudence. For example, the Court could have explained more in detail why and how women and girls were being particularly targeted through gendered violence, or by confronting different ethnic and religious communities in light of a given socio-economic, political and cultural context. It is for now also difficult to establish with greater certainty whether there is any direct link of these recent jurisprudential developments to the ICC Prosecutor's policy papers and whether one can already recognise in them a new trend emerging at the Court 
to give more thorough and detailed consideration to issues of intersectionality in its future rulings. The truth is, however, that the Court has yet to develop comprehensive and uniform intersectional methodologies and expertise for prosecuting and adjudicating situations and cases involving mass abuses grounded in inequalities, and ultimately, ensure that they are actually and fully applied in practice.

In this regard, I would like to put forward some 'pro et contra intersectionality' considerations (pros and cons) that can inform debates regarding purpose and added conceptual and socio-legal value of intersectionality analysis in applying and interpreting international criminal law, as well as more practical issues and concerns of implementing intersectionality in the field of international criminal justice more generally. This kind of reflection can help us better assess how the actual implementation of intersectionality would really work in the concrete political and socio-legal context of the Court.

\subsection{The Case for Including Intersectionality in the Court's Consideration of Mass Atrocities}

The above review of a sampling of relevant cases before the Court has demonstrated how intersectionality can be useful in international criminal law for understanding the impact of interlaced identities and statuses of individuals and groups in relation to their experiences with mass atrocities and any mass crimes-related issues. That said, a multi-faceted discriminatory (political, racial, ethnic, religious, gender) motive invoked, for example, for the commission of genocide, persecution and sexual abuses is undoubtedly relevant to the Court's consideration of such issues as the development of case hypotheses and the analysis of crime patterns; the selection, investigation and prosecution strategies; the identification of the gravity requirement (both in terms of admissibility of a particular case under Article $17(1)(d)$ of the Rome Statute as well as for the purpose of sentencing); the screening, interviewing, and testimony of witnesses; imposing of criminal sentence; and a certain degree of individualization when awarding reparations. Even on appeal, submissions and judicial decisions may become fully informed by the intersectionality arguments. While the cases presented above reveal the Court's developing awareness of multiple and intersecting forms of discriminatory targeting, a progression towards more intersectionality-focused thinking in its practice remains slow, non-linear and inconsistent.

Approaching targeted violence from the intersectionality perspective and addressing it through more inclusive and nuanced contextualization is vital for being able to cope with intricate network of multiple reasons, forms and dimensions of discrimination that often underpin mass atrocities. Intersectionality 
analysis is therefore powerful in unravelling the complex interaction between social and political factors of the broader criminal context and mass crimes. Intersectional thinking can also help explain how victimization in many contexts is driven by patterns of intersectionality that lead to specific subgroups of population being particularly targeted or affected during mass violence. Intersectionality can enlighten the ICC Prosecutor and judges as to the various forms and aspects of discrimination (as aggravating factors of criminal conduct), and their overall impact on multiple vulnerabilities of victims. This specific and additional knowledge may guide the Prosecutor in the selection of cases for investigation and ICC judges in their assessment of the severity in sentencing and in ordering reparations. In line with the principles of equity, proportionality, effectiveness and dissuasion of punishment and because of particularly harmful consequences of such a compound criminal conduct resulting from a combination/intersection of two or more targeted identities, the penal sentence should be stricter than in other criminal cases not involving cumulative discriminatory intent or where only one single identity has been targeted.

Intersectionality moreover links various social factors and reasons for discrimination (gender, race, ethnicity, religion, political affiliation, age, sexual orientation, disability and others) to the socio-economic, political and cultural context in which mass atrocities occur in order to better understand the true nature and impact of such abuses and the inflicted harms. By way of intersectionality analysis, the ICC Prosecutor can, for example, identify the whole structure of inequalities and seek to explain this reality when drafting charges and tying to explain a specific and qualified genocidal/persecutory intent as part of widespread and systematic attack directed against the civilian population. Similarly, adjudicating mass atrocities in intersectionality-sensitive manner can help ICC judges more accurately and fairly assess how multiple social factors underpinning genocide, persecution or gender-based atrocities and their interaction contributed to discriminatory targeting, violence and abuse.

Correctly understanding and applying intersectionality can also inform other areas, issues and actors of relevance to international criminal justice, such as facilitating access to evidence during investigations through better understanding of ethnic, gender and religious aspects when working with victims and affected communities; in engaging expert witnesses and victims representatives (for example, through submissions by the Office of Public Counsel for Victims), thus empowering victims in the judicial process to adequately present multiple, this is gender/ethnicity/age/religion-connected harms they suffered; as well as in working out gender/ethnicity/age/religion-inclusive and sensitive reparations that aim to address and remedy the structural 
inequalities and their multifaceted nature which made the victims vulnerable in multiple ways. ${ }^{42}$ As noted earlier, collective reparations with individualised components are to be ordered and they should go to the heart of the specific nature of mass atrocities grounded in multiple and intersecting forms of discrimination and should compensate as much as possible the double, triple or multiple hardship that victims went through because of their situation as women, children, older persons, Muslims, Christians, or homosexuals belonging to a particular racial or ethnic group. In other words, reparation measures should fully recognize and effectively address the true nature and dynamics of multiple and intersectional discrimination (this is, interconnected inequalities) at the root of mass abuses.

Application of intersectionality analysis by the Court can be particularly helpful in its prosecution and adjudication of persecution as the crime against humanity with discriminatory nature. In this respect, the ICC Prosecutor's selection of situations and cases, labelling and phrasing of the charges, as well as judicial interpretation and reasoning can considerably benefit from placing greater emphasis on intersectional dimensions of particular situations and cases in the Court's handling of the crime of persecution. The Court's acknowledgement and careful analysis of the overlap and interaction between different identities - such as race, ethnicity, religion, gender, political affiliation, age - as reasons for multiple and intersectional discrimination experienced, for example, by persecuted ethnic minority's women may prevent situations in which the victims' complex experiences of a double- or even triple-identity targeting would otherwise fall into the negative legal space or remain outside of specific legal protection. Moreover, an intersectionality-inclusive interpretation of discriminatory dimensions of the genocide and persecution cases can help the Court identify an adequate and tailored - this is, 'optimally customized' $^{43}$ remedy in individual cases, thus going beyond a common unisectional conception of discriminatory targeting through mass atrocities to capture multiple risks and harms that such crimes typically entail.

In closing, while there still is a lot of room for the Court to actually and fully implement intersectionality in its case law, it remains to be seen what concrete steps the ICC Prosecutor and judges will choose to take in this regard. But if the Court eventually embarks on such an 'intersectionality-evolving case law' project, it is also likely to face some issues related to its practical implications. Since these difficulties are by no means negligible, they merit some closer

42 A.N. Davis, 'Intersectionality and International Law: Recognizing Complex Identities on the Global Stage', 28(1) Harvard Human Rights Journal (2015) 205-243, p. 239.

43

Ibid., p. 233 . 
examination. The next subsection discusses some of the actual practicalities of building cases of mass atrocities based on intersectional theories of crimes.

\subsection{Plausible Pushbacks against Including Intersectionality in the Court's Practice}

As the foregoing discussion has illustrated, a turn towards a more intersectional consideration of mass atrocities by the Court would undoubtedly bring many advantages in terms of both combating impunity, as well as achieving greater balance between retributive, restorative and transformative goals of international criminal justice. On the other hand, however, one also needs to admit that the argument for a greater implementation of intersectionality in the context of international criminal prosecution and adjudication may bring with it some major challenges in practice.

The first potential objection to the development of a more intersectionalityoriented jurisprudence by the Court has to do with the fact that intersectional consideration of mass atrocities is, by its nature, victim-focused, thus making the perspective of a perpetrator seem less important. As a result, the Court's findings and interpretations may (appear to) be less favourable to the position of a suspect/defendant. This particular challenge could be overcome by counterbalancing the intersectionality analysis with witness testimonies and documentary evidence more regardful of the perpetrator's position. ${ }^{44}$ In this way, the Court's decisions should become more balanced and objective.

Another major concern regarding the application of intersectionality in the international criminal law context pertains to the methodological issues. The above analysis of the relevant case law of the Court has revealed that the ICC Prosecutor and judges approached the issue of intersectionality mainly by conducting qualitative assessment of complex factual scenarios. While it is true that these qualitative findings of intersectionality analysis could and should be complemented, objectivized and strengthened by adding more representative and reliable data through quantitative methods (for example, intersectionality-focused surveys to victims and witnesses), ${ }^{45}$ it is questionable whether the Court is actually in a position to obtain such data and conduct research statistics.

Given that the ICC Prosecutor has more often than not struggled to garner solid evidence and has also had a difficult time with regard to proving artocity crimes, an argument could be made that prosecuting mass atrocities as intersectional would require the Prosecutor to prove that victims were targeted

44 Beringola, supra note 6, p. 109.

45 Ibid. 
on the basis of multiple protected characteristics. In practice, the Prosecutor has mostly relied on witness testimonies and has had no or only very limited access to the different forms of quantitative approaches. Moreover, there has been lack of investigative resources and success at the Court.

Other pitfalls and potential pushbacks against incorporating intersectionality into the Court's case law can be put forward as well. For example, if the ICC Prosecutor made an intersectional claim more explicitly, this could also mean that defence counsel had more points where they could make a plausible case that the theory of crimes on which the prosecution based its case was not, in fact, consistent with what really occurred. This may also be one of the reasons why the Prosecutor has normally relied on cumulative conceptual understanding of discriminatory targeting that involved multiple and compound identities. Indeed, such an approach pursued by the ICC Prosecutor has allowed individual parts and forms of discrimination to be disproved without affecting the overall theory of crimes. However, most feminist and critical race theory scholars would agree that prosecution-oriented legal strategies of the Court can ill afford to ignore the harmful intersections of gender and race with other targeted identities and statuses, including national, ethnic, or social origin, culture, religion or belief, age, birth, disability, sexual orientation and political or other opinion, and should therefore necessarily embed intersectionality. After all, this is also the existing policy commitment undertaken by the отР itself.

Given the Court's budgetary restraints, one could also argue that pursuing intersectional theories of mass atrocities in its practices is unrealistic because of lack of financial and other resources and because of the Assembly of State Parties' probable reluctance to grant more funding in support of the intersectionality implementation efforts. In response to such budgetary concerns as well as those related to lack of the relevant expertise, it should be noted that the Court's greater implementation of the intersectionality analysis in its prosecutorial and adjudicatory practices would not require considerably more (financial and human) resources than it is presently the case. What is really needed is the Prosecutor's, judges' and victims representatives' increased cognizance of the issues of intersectionality and of particular strategies and methods of going about their treating at key stages of the international criminal proceeding. This could be achieved, for example, by organising appropriate training seminars or workshops for prosecutorial, judicial and other ICC staff (including the Office of Public Counsel for Victims), as well as through engaging in the Court's trials socio-cultural expert witnesses who can provide the necessary background knowledge about social, cultural, historical, religious and political contexts to highlight intersecting dimensions of mass crimes and thus set up an adequate explanatory framework for judicial deliberations 
and decisions. In any event, the Court can and should draw on the existing jurisprudence and practices of earlier ad hoc international criminal tribunals for the former Yugoslavia and Rwanda and, in particular, international and regional human rights adjudicative bodies, as it actually did to some extent in its recent reparations order in Ntaganda (by relying on the advanced case law on reparations of the Inter-American Court of Human Rights).

Naturally, the ICC will need to work out the concrete ways, methods and means to deal with these and other practical problems. But one thing remains certain - if the international criminal justice system with the ICC at its core is ever going to reach its maturity and high legitimate value, it will necessarily have to acknowledge these difficulties at some point and try to do what it takes to pull off its 'intersectionality of atrocity crimes' jurisprudential enterprise.

\section{Acknowledgement}

This article is part of a project that has received funding from the European Union's Horizon 2020 research and innovation programme under grant agreement No. 746768 . 